UNIVERSITE DE LAUSANNE - FACULTE DE BIOLOGIE ET DE MEDECINE

Département Universitaire de Médecine et Santé Communautaires

Institut Universitaire de Médecine Sociale et Préventive

\title{
Smoking offsets the metabolic benefits of parental \\ longevity in women: the CoLaus study
}

\section{THESE}

préparée sous la direction du Docteur Murielle Bochud, Privat-Docent avec la co-direction du Professeur Fred Paccaud, Directeur de l'Institut Universitaire de Médecine Sociale et Préventive et présentée à la Faculté de biologie et de médecine de l'Université de Lausanne pour l'obtention du grade de

DOCTEUR EN MEDECINE

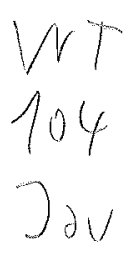

\author{
par \\ Jérôme Patrick JAUNIN \\ BHTE 3505
}

Médecin diplômé de la Confédération Suisse

Originaire de Fey (VD)

Lausanne

2009 


\section{Rapport de synthèse}

Objectif: nous avons regardé si les sujets dont les parents vivaient plus longtemps présentaient des niveaux plus faibles de facteurs de risques cardiovasculaires, y compris pour le syndrome métabolique.

Méthodes: nous avons analysé les données d'un échantillon représentatif de la population suisse (1163 hommes et 1398 femmes) âgé de 55 à 75 ans, de la ville de Lausanne. Les participants ont été stratifiés par nombre de parents $(0,1,2)$ qui ont vécu jusqu'à 85 ans ou plus. Les associations entre la longévité parentale et les facteurs de risques cardiovasculaires ou les variables métaboliques associées ont été analysées au moyen de régressions linéaires multiples.

Résultats: la prévalence ajustée pour l'âge du syndrome métabolique varie de $24.8 \%, 20.5 \%$ à $13.8 \%$ chez les femmes $(\mathrm{P}<0.05)$ et de $28.8 \%, 32.1 \%$ à $27.6 \%$ chez les hommes (non significatif) pour 0,1 et 2 parents à forte longévité. L'association entre la longévité parentale et la prévalence du syndrome métabolique est particulièrement forte pour les femmes qui n'ont jamais fumé. Dans ce groupe, les femmes qui ont 2 parents à forte longévité ont un BMI plus faible et un tour de taille moins grand. Chez les gens qui n'ont jamais fumé, pour les deux sexes, les niveaux moyens ( $95 \%$ d'intervalle de confiance) et ajustés de cholestérolHDL étaient de $1.64(1.61-1.67), 1.67(1.65-1.70)$ et $1.71(1.65-1.76) \mathrm{mmol} / \mathrm{L}$ pour 0,1 et 2 parents à forte longévité $(\mathrm{P}<0.01)$, respectivement. La tendance n'était pas significative chez les anciens fumeurs et fumeurs actuels.

Conclusions: la longévité parentale est associée à un meilleur profil métabolique chez les femmes, mais pas chez les hommes. Les avantages métaboliques du fait d'avoir des parents âgés sont fortement atténués par le tabagisme.

Mots clés: vieillissement; maladie cardiovasculaire; obésité; épidémiologie 


\section{Smoking offsets the metabolic benefits of parental longevity in women: the CoLaus study}

Running title: parental longevity and the metabolic syndrome

Jerome Jaunin, $\mathrm{MD}^{1}$, Murielle Bochud, $\mathrm{MD}, \mathrm{PhD}^{1}$, Pedro Marques-Vidal, $\mathrm{MD}, \mathrm{PhD}^{1,2}$, Peter Vollenweider, $\mathrm{MD}^{3}$, Gérard Waeber, $\mathrm{MD}^{3}$, Vincent Mooser, $\mathrm{MD}^{4}$, Fred Paccaud, MD, $\mathrm{MSc}^{1}$

1. University Institute of Social and Preventive Medicine (IUMSP), University of Lausanne,

Switzerland

2. Cardiomet, CHUV, Lausanne, Switzerland

3. Department of Medicine, Internal Medicine, CHUV, Lausanne, Switzerland

4. Genetics Division, GlaxoSmithKline, Philadelphia, Pennsylvania, U.S.A.

Corresponding author: $\quad$ Dr. Murielle Bochud, $\mathrm{MD}, \mathrm{PhD}$

Community Prevention Unit

Institute of Social and Preventive Medicine

Rue du Bugnon 17

CH-1005 Lausanne, Switzerland

Phone: ++41213147254

Fax: ++41213147373

Email: Murielle.Bochud@chuv.ch

Word count, abstract: 196

Word count, manuscript: 2882

Number of figures: 2

Number of tables: 5

Supplementary tables: 4 


\section{ABSTRACT}

Objective: We evaluated whether subjects with long-lived parents show lower levels of cardiovascular risk factors, including the metabolic syndrome.

Methods: We analyzed data from a Swiss population-based sample (1163 men and 1398 women) aged 55-75 years from Lausanne. Participants were stratified by number of parents $(0,1,2)$ who survived to 85 years or more. The associations of parental longevity with cardiovascular risk factors and related metabolic variables were analyzed using multiple linear regressions.

Results: Age-adjusted metabolic syndrome prevalence varied from $24.8 \%, 20.5 \%$ to $13.8 \%$ in women $(\mathrm{P}<0.05)$ and from $28.8 \%, 32.1 \%$ to $27.6 \%$ in men (not significant) with 0,1 and 2 long-lived parents. The association between parental longevity and metabolic syndrome prevalence was particularly strong in women who had never smoked. In this group, women with 2 long-lived parents had lower BMI and smaller waist circumference. In never-smokers of both genders, mean (95\% CI) adjusted HDL-cholesterol levels were 1.64(1.61-1.67), 1.67(1.65-1.70) and 1.71(1.65-1.76) $\mathrm{mmol} / \mathrm{L}$ for 0,1 and 2 long-lived parents $(\mathrm{P}<0.01)$, respectively. The trend was not significant in former and current smokers.

Conclusions: In women, not in men, parental longevity is associated with a better metabolic profile. The metabolic benefits of having long-lived parents are offset by smoking.

Keywords: aging; cardiovascular disease; obesity; epidemiology 


\section{INTRODUCTION}

Longevity aggregates in families, and parents who live longer generally have offspring with longer life expectancy (Atzmon et al. 2004; Martin et al. 2007; Perls et al. 2002; Terry et al. 2007). In mortality studies, increased longevity has been mainly attributable to reduced cardiovascular mortality (Ikeda et al. 2006; Menotti et al. 2006; Rosengren et al. 2002). It has therefore been hypothesized that longevity results from reduced susceptibility to cardiovascular disease (Terry et al. 2004; Tunstall-Pedoe et al. 1999).

Parental longevity has been associated with a favorable cardiovascular risk profile in several studies (Barzilai et al. 2001; Hammond et al. 1971; Reed et al. 2003; Terry et al. 2003; Terry et al. 2004; Terry et al. 2007; Yarnell et al. 2003; Zureik et al. 2005). In the Framingham Offspring study (Terry et al. 2007), offspring with long-lived parents had a more favorable cardiovascular risk profile with lower increase in blood pressure and Framingham risk score during follow-up compared to offspring whose parents died at a younger age. To our knowledge, there is little information on the biological profile of offspring of long-lived parents and on the effect of additional cardiovascular and metabolic markers such as insulin, adiponectin, leptin and homocystein, and inflammation markers such as ultrasensitive Creactive protein (CRP) and uric acid.

In an effort to expand our understanding of the effect of parental longevity on cardiovascular diseases, we performed detailed analyses of the relationship between parental longevity and a large array of metabolic variables in the population-based CoLaus Study in Lausanne, Switzerland, a resource which has already been used to examine the phenotypic and genetic determinants of various traits (Firmann et al. 2008; Marques-Vidal et al. 2007; MarquesVidal et al. 2008; Rodondi et al. 2008; Sandhu et al. 2008). We restricted these analyses to subjects aged 55 or more to avoid left-censoring of parental longevity information (i.e. parents of young subjects are more likely to be alive and their longevity is therefore unknown). 


\section{METHODS}

\section{Study population}

The study was approved by the Ethics Committee of the Faculty of Medicine of Lausanne. Recruitment began in June 2003 and ended in May 2006 (Firmann et al. 2008). The complete list of Lausanne inhabitants aged $35-75$ years $(n=56,694)$ was provided by the population registry of the city. A simple non-stratified random sample of $35 \%$ of the overall population was drawn. Inclusion criteria were: a) written informed consent; b) age between 35 and 74 years; c) willingness to donate data, blood and urine samples and d) Caucasian descent. Out of the 6188 participants, we excluded 3509 subjects who were younger than 55 years. In addition, we excluded 108 subjects due to missing data on parental longevity and 10 for missing covariates, so that 2561 subjects were included in the present analysis. In this group, 1298 individuals had neither parent alive or had both their parents deceased before they reached 85 years, 991 individuals had one parent alive or one parent deceased after 85 , and 272 had both parents either still alive or deceased after the age of 85 .

\section{Questionnaire data}

Trained health professionals used a standardized questionnaire on socio-demographic characteristics and family history. The following questions were asked: "Is your father still alive?"; "If yes, how old is he?" ;"If no, at what age did he die?" The same questions were asked about the mother of each participant.

\section{Assessment process and data collection}

Participants attended the outpatient clinic of the University Hospital Center of Lausanne (CHUV) in the morning after an overnight fast. For the purpose of this analysis, smoking was defined as present if a participant reported to be a current smoker at the time of examination, alcohol consumption was defined as present for participants who reported drinking alcohol at least once a day.

Body mass index (BMI) was defined as weight in $\mathrm{kg}$ divided by height in meters squared. Waist was measured over the unclothed abdomen at the narrowest point between the lowest rib and the iliac crest. Blood pressure and heart rate were measured three times on the left arm after at least a 10 minute rest in the seated position, using a clinically validated automatic 
oscillometric device (Omron HEM-907, Matsusaka, Japan)(El Assaad et al. 2002), with an appropriately sized cuff. The average of the second and third readings was used for analyses. Hypertension was defined as a mean systolic blood pressure (SBP) $\geq 140 \mathrm{~mm} \mathrm{Hg}$ and/or a diastolic blood pressure (DBP) $\geq 90 \mathrm{~mm} \mathrm{Hg}$ and/or presence of antihypertensive drug treatment.

A venous blood sample was collected in each participant under fasting conditions ( 8 hours requested). Blood tubes were centrifuged at $1,500 \mathrm{rpm}$ for 10 minutes at $4^{\circ} \mathrm{C}$ within $2 \mathrm{~h}$. of admission. The CHUV Clinical Laboratory, which is ISO 9001 certified and regularly checked by the Swiss Centre for Quality Control, conducted all measurements in a Modular P apparatus (Roche Diagnostics, Switzerland). The analytical procedures for biological markers and clinical chemistry methods have been described previously (Firmann et al. 2008). Diabetes was defined as a fasting blood glucose $\geq 7 \mathrm{mmol} / 1$ and/or presence of any antidiabetic drug (including insulin). Hypercholesterolemia was defined as a fasting blood cholesterol $\geq 6.2 \mathrm{mmol} / 1$ and/or presence of lipid lowering drugs.

\section{Statistical analyses}

Statistical analyses were performed using Stata 9.2 (Stata Corp, College Station, USA). Quantitative data were expressed as means \pm standard deviations. Qualitative data were expressed as number of subjects and percentage. Participants were stratified by the number of parents who survived to age 85 or more as follows: 0 parent alive, 1 parent alive, or both parents alive at age 85 or more. We chose a cut-off of 85 years because this is the commonly accepted definition of the oldest old (Suzman et al. 1985).

We first conducted simple linear regression across the three categories of parental longevity, coded as 0,1 and 2 for the number of parents alive or dead at age 85 or older. We compared these unadjusted results with (1) full models not adjusted for BMI, (2) full models adjusted for BMI. Full models included age, sex, alcohol (coded as 1 if at least one standard drink a day and 0 otherwise), tobacco consumption and educational level (as a proxy for socioeconomic status). For blood pressure, further adjustment was made for antihypertensive treatment; for lipid markers, further adjustment was made for lipid-lowering treatment. For height, full adjustment included weight instead of BMI; for weight, full adjustment included 
height instead of BMI; for waist, full adjustment included BMI. We tested all models for an interaction of parental longevity with the participant's sex. Results were stratified by sex whenever this interaction was significant. We also compared the effects of parental longevity in former or current smokers versus never smokers.

We calculated ten-year coronary heart disease (CHD) risk score using the Framingham risk function (Wilson et al. 1998) and compared trend across the three parental categories of parental longevity using a non-parametric test for trend as implemented in the Stata nptrend function. The presence of metabolic syndrome was defined using the Adult Treatment Panel III definition of the National Cholesterol Education Program (Adult Treatment Panel III 2002), and trends across categories of parental longevity were assessed in a similar way. Ageadjusted prevalence was calculated using the direct standardization method (proportion function) in Stata.

\section{RESULTS}

\section{Participants' characteristics}

Participants' characteristics are listed in Table 1. Women had lower BMI, weight and height, lower education levels and prevalence of alcohol and tobacco consumption than men.

\section{Associations of parental longevity with anthropometric variables}

BMI was much lower in women with longer-lived parents than in other women (Table 2). This was attributable to both lower weight and higher height. The weight difference between women with 2 and 0 long-lived parents was $3.8 \mathrm{~kg}$. Women with longer-lived parents had lower waist circumference, even after adjusting for BMI. Similar non significant trends were found in men.

In female never smokers, a significant trend was observed towards lower BMI, weight and waist circumference with increasing parental longevity (Figure 1). Similar trends, but only of borderline significance, were found in female former and current smokers. No such trends were observed in men, regardless of smoking status (Figure 1). 
Associations of parental longevity with cardiovascular risk factors

For most variables analyzed (Table 3), we observed trends towards lower cardiovascular risk profile as parental longevity increased. With the exception of pulse pressure, these trends were not significant after adjustment for BMI. The fact that adjustment for BMI attenuated these trends suggests that the lower cardiovascular risk profile associated with parental longevity is mediated, in part, by BMI. We found no significant interaction of parental longevity with sex for these variables. In never smokers (supplementary table 3a), fully adjusted (including BMI) means (95\% CI) for HDL-cholesterol levels were 1.64 (1.61-1.67), $1.67(1.65-1.70)$ and $1.71(1.65-1.76) \mathrm{mmol} / \mathrm{L}$ for 0,1 and 2 long-lived parents, respectively $(\mathbf{p}<0.01)$. The corresponding means were 1.56 (1.54-1.59), $1.57(1.55-1.59)$ and 1.58 (1.54$1.62)$ in the group of former and current smokers $(\mathbf{p}>0.05)$ (supplementary table $3 \mathbf{b}$ ).

We conducted similar analyses with other selected variables: the results are summarized in Table 4. CRP, liver enzymes, leptin and uric acid all showed significant trends across categories of parental longevity, but only AST remained significant after adjustment for BMI. All these variables showed a trend towards better health condition with longer parental longevity. Analyses stratified by smoking status are available in supplementary table $4 \mathrm{a}$ and $4 b$.

Table 5 shows how the Framingham Risk Score evolves through each category of parental longevity. A significant trend towards better cardiovascular profile was observed in women whose parents lived the longest. These results confirmed what we obtained for separate cardiovascular risk factors. We found a lower Framingham Risk Score among female never smokers with long-lived parents, but not among former or current smokers.

\section{Associations of parental longevity with the metabolic syndrome}

Women, but not men, with longer-lived parents had lower age-adjusted prevalence of the metabolic syndrome (Figure 2). In women, the age-adjusted prevalence of the metabolic syndrome varied from $24.8 \%, 20.5 \%$ to $13.8 \%$ for 0,1 and 2 long-lived parents, respectively, whereas in men the corresponding values were $28.8 \%, 32.1 \%$ and $27.6 \%$. When stratifying by smoking status, female never smokers showed a strong and significant trend for lower prevalence in metabolic syndrome with increasing parental longevity. Female former or current smokers and men didn't show such a trend (Figure 2). These results suggest that, in 
women, the beneficial effects of parental longevity on the metabolic syndrome are offset by smoking.

\section{DISCUSSION}

We found that increased parental longevity was strongly associated with decreased prevalence of the metabolic syndrome in women, but not in men. To our knowledge, this is the first time that this association has been reported. In women, the prevalence of the metabolic syndrome decreased from $24.8 \%$ to $13.8 \%$ across categories of increasing parental longevity. The size of this effect is remarkable considering that parental longevity was only reported, and not observed. These findings outline the power of family history to capture increased susceptibility to the clustering of cardiovascular risk factors. Our results are consistent with previous studies showing that longevity is associated with reduced cardiovascular mortality (Ikeda et al. 2006; Menotti et al. 2006; Rosengren et al. 2002). We provide an additional dimension to this picture by showing that this lower cardiovascular mortality is partly mediated by the clustering of risks as observed in the metabolic syndrome.

Gender differences in cardiovascular morbidity and mortality are well known (MullerNordhorn et al. 2008). In this study, an inverse association between parental longevity and prevalence of the metabolic syndrome was observed in women, but not in men. Similarly, the inverse association between Framingham Risk Score and parental longevity was only observed in women. This may reflect the fact that women are fitter than men. Following this perspective, environmental or genetic determinants of increased longevity might show their effects more clearly in subjects who are healthier. We cannot exclude that part of the observed sex differences are explained by the fact that daughters give more accurate information than sons regarding their parental longevity. However, in the field of cardiovascular risk factors, several studies showed no clear difference in the validity of family history between men and women (Bensen et al. 1999; Karter et al. 1999; Murabito et al. 2004). Compared to men, the conjunction of lower BMI, lower prevalence of metabolic syndrome, and lower Framingham Risk Score in women may explain why the heredity of longevity was greater among women than men. Our results suggest that all cardiovascular risk factors need to be low for the heredity of longevity to become apparent. The fact that male gender itself may be seen as a cardiovascular risk factor could explain why we observed no association between parental longevity and cardiovascular clustering in men. 
Strong, further evidence to back up this hypothesis is that the association between parental longevity and cardiovascular risk varied according to smoking status. First, increased parental longevity was associated with lower prevalence of the metabolic syndrome mainly in women who had never smoked. Furthermore, the association of increased parental longevity with lower weight, BMI and waist, and with higher HDL-cholesterol levels was much stronger in female never smokers than in female former or current smokers. Smoking, through its gerontogenic effects (Bernhard et al. 2007; Martin 2000), could reduce or neutralize the beneficial effect of increased parental longevity on the cardiovascular risk profile. This could also be the case for other acquired risk factors.

Our results underline the importance of BMI as a link between parental longevity and cardiovascular risk factors. Before adjusting for BMI, increased parental longevity was significantly associated with lower levels of several cardiovascular risk factors. Several associations (i.e., with systolic blood pressure, HDL-cholesterol and triglycerides) were attenuated after correcting for BMI. Moreover, the association of increased parental longevity with lower levels of inflammation markers (e.g., lower CRP) disappeared after correcting for BMI. Hence, the lower cardiovascular risk observed in offspring of long-lived parents could be partially mediated by lower BMI. Our findings are consistent with the association of obesity with cardiovascular risk factors clustering (Grundy 2007). Our findings are also consistent with the observation that obesity is a cardiovascular risk factor in primary prevention settings (i.e. very low prevalence of cardiovascular disease in our sample)(Yusuf et al. 2004). Since BMI results from genetic as well as non-genetic determinants, it may not only act as a mediator but also as a confounding factor in the association between parental longevity and cardiovascular risk. The improved health status associated with increased parental longevity may be partly due to shared environmental factors, including diet, between parents and their offspring. This highlights the importance of properly accounting for the complex role of $\mathrm{BMI}$ in this context.

\section{Study limitations}

Our study suffers from some limitations. First, parental longevity was not measured but only reported. This may lead to some nondifferential misclassification of parental longevity that should rather weaken the true underlying associations. Therefore, we may have underestimated the impact of parental longevity on the participants' cardiovascular risk 
profile. Second, we have no information on parental BMI. Although this limits our capacity to understand the underlying pathophysiological processes, it does not decrease the usefulness of this simple and readily accessible piece of information (parental longevity) in clinical practice. Third, we have no information on smoking habits of parents. As parental and childhood smoking habits are closely related (Rainio et al. 2008), it is unlikely that the associations observed in never-smoking women are confounded by parental smoking. However, we cannot evaluate the impact of parental smoking on offspring's smoking status and how this might affect the absence of association of metabolic syndrome with parental longevity. Differences between men and women suggest a possible hormonal explanation for women's better profile. As $98.4 \%$ of women were postmenopausal, we cannot explore the link between sex hormones and longevity in our study. This should be further investigated. Another limitation is that we cannot exclude a healthy volunteer bias. If our hypothesis that better fitness favors the detection of the beneficial effects of parental longevity is true, the fact that our study participants could be, on average, healthier than individuals from the general population, would lead to an overestimation of the beneficial effect of parental longevity on cardiovascular risk as compared to a sample devoid of healthy volunteer bias. We have not conducted separate analyses by former and current smoking status because of small sample sizes. As former smokers might have a metabolic benefit and be more health-conscious than current smokers, we would expect intermediate findings in former smokers. Finally, the low participation rate limits the external validity of our findings. Such participation rate is however comparable to those observed in MONICA surveys in France and Switzerland (Wolf et al. 2005). The magnitude of the non-participation bias is not proportional to the percentage of non-participants (Galea et al. 2007) and a study on representativeness observed that people with risky behaviours participated in the same proportions as people without risk factors (Taylor et al. 2006). Moreover, in CoLaus, the age, gender and zip code distributions in participants were comparable to those observed in the source population (Firmann et al. 2008). As the study was restricted to Caucasians, our findings may not apply to other ethnic groups.

\section{CONCLUSIONS}

Although each single cardiovascular risk factor was only moderately associated with parental longevity, the clustering of cardiovascular risk factors, as reflected by the prevalence of the metabolic syndrome, was strongly associated with parental longevity in women. This gender 
difference, together with the observation that the beneficial effect of parental longevity was only present in never smokers, suggests that smoking may offset the benefits of having longlived parents. 


\section{ACKNOWLEDGEMENTS}

We would like to thank all the study nurses and medical doctors who participated to the data collection. We are grateful to all study participants.

\section{FUNDING}

The CoLaus study was supported by research grants from GlaxoSmithKline and from the Faculty of Biology and Medicine of Lausanne, Switzerland. MB is supported by grants from the Swiss National Foundation for Science (PROSPER: 3200BO-111362/1 and 3233BO111361/1).

\section{CONFLICT OF INTEREST}

The authors declare that there are no conflicts of interest. VM is a full time employee of GlaxoSmithKline.

\section{CONTRIBUTORS}

$\mathrm{JJ}$ and MB had full access to all the data in the study and take full responsibility for the integrity of the data and the accuracy of the data analysis. Study concept and design: PV, GW, VM and FP. Acquisition of data: PV. Analysis and interpretation of data: JJ, MB, PMV. Drafting of the manuscript: JJ and $\mathrm{MB}$. Critical revision of the manuscript for important intellectual content: PMV, PV, GW, VM, FP. 
Table 1: Participants' Characteristics, Overall and by Sex*. The CoLaus study, Lausanne, Switzerland (2003-2006).

\begin{tabular}{|c|c|c|c|}
\hline Characteristic & $\begin{array}{l}\text { TOTAL } \\
(n=2561)\end{array}$ & $\begin{array}{l}\text { MEN } \\
(n=1163)\end{array}$ & $\begin{array}{l}\text { WOMEN } \\
(n=1398)\end{array}$ \\
\hline $\begin{array}{l}\text { Age (years) } \\
\text { Body mass index }\left(\mathrm{kg} / \mathrm{m}^{2}\right)\end{array}$ & $\begin{array}{l}63.6 \pm 5.6 \\
26.6 \pm 4.6\end{array}$ & $\begin{array}{l}63.6 \pm 5.5 \\
27.4 \pm 4.0\end{array}$ & $\begin{array}{l}63.6 \pm 5.6 \\
25.9 \pm 4.9\end{array}$ \\
\hline Height $(\mathrm{cm})$ & $167.0 \pm 9.0$ & $173.5 \pm 7.1$ & $161.6 \pm 6.4$ \\
\hline Weight $(\mathrm{kg})$ & $74.5 \pm 15.1$ & $82.7 \pm 13.2$ & $67.7 \pm 13.0$ \\
\hline \multicolumn{4}{|l|}{ Education level $(\%)$} \\
\hline Basic & 21.7 & 15.3 & 27.0 \\
\hline Apprenticeship & 41.0 & 42.5 & 39.8 \\
\hline High school certificate & 9.5 & 8.3 & 10.4 \\
\hline Higher degree & 14.1 & 15.7 & 12.8 \\
\hline University degree & 13.6 & 18.1 & 9.9 \\
\hline \multicolumn{4}{|l|}{ Treatment } \\
\hline Antihypertensive treatment $(\%)$ & 31.5 & 35.8 & 28.0 \\
\hline Antidiabetic treatment $(\%)$ & 6.9 & 10.6 & 3.8 \\
\hline Lipid lowering treatment (\%) & 20.5 & 25.0 & 16.7 \\
\hline Alcohol consumption (\%) & 31.8 & 44.6 & 21.1 \\
\hline Current smokers $(\%)$ & 21.7 & 24.9 & 19.0 \\
\hline Former-smokers (\%) & 37.5 & 47.7 & 28.9 \\
\hline \multicolumn{4}{|l|}{ Personal history } \\
\hline Acute myocardial infarction (\%) & 2.9 & 5.0 & 1.1 \\
\hline Stroke $(\%)$ & 1.8 & 2.3 & 1.4 \\
\hline Diabetes $(\%)$ & 10.9 & 16.9 & 6.0 \\
\hline \multicolumn{4}{|l|}{ Father's history } \\
\hline Acute myocardial infarction $(\%)$ & 17.5 & 16.7 & 18.2 \\
\hline Stroke $(\%)$ & 11.1 & 10.5 & 11.6 \\
\hline Diabetes $(\%)$ & 7.9 & 8.1 & 7.8 \\
\hline \multicolumn{4}{|l|}{ Mother's history } \\
\hline Acute myocardial infarction (\%) & 9.1 & 7.2 & 10.7 \\
\hline Stroke $(\%)$ & 11.4 & 9.5 & 13.0 \\
\hline Diabetes (\%) & 11.5 & 9.8 & 12.8 \\
\hline
\end{tabular}

*Data are means $\pm \mathrm{SD}$, unless stated otherwise. 
Table 2. Anthropometric Variables by Parental Longevity Categories. The CoLaus study, Lausanne, Switzerland (2003-2006).

\begin{tabular}{|c|c|c|c|c|}
\hline Trait & Model & 0 parent & 1 parent & 2 parents \\
\hline \multirow[t]{3}{*}{ Height $(\mathrm{cm})$} & Unadjusted & $166.6(166.1-167.0)$ & $167.3(166.9-167.7)$ & $168.1(167.3-168.9) \ddagger$ \\
\hline & Model 1 & $166.8(166.5-167.1)$ & $167.2(166.9-167.5)$ & $167.6(167.0-168.1)^{\dagger}$ \\
\hline & Model 2 & $166.7(166.4-167)$ & $167.2(167.0-167.5)$ & $167.8(167.2-168.3)+$ \\
\hline \multicolumn{5}{|l|}{ Weight (kg) } \\
\hline \multirow[t]{3}{*}{ Men } & Unadjusted & $82.8(81.7-83.8)$ & $82.6(81.7-83.5)$ & $82.4(80.7-84.1)$ \\
\hline & Model 1 & $82.7(81.6-83.7)$ & $82.6(81.8-83.5)$ & $82.6(80.9-84.3)$ \\
\hline & Model 2 & $82.8(81.9-83.7)$ & $82.6(81.8-83.4)$ & $82.3(80.7-83.9)$ \\
\hline \multirow[t]{3}{*}{ Women } & Unadjusted & $68.7(67.8-69.6)$ & $67(66.2-67.7)$ & $65.2(63.6-66.8)$ \\
\hline & Model 1 & $68.5(67.6-69.4)$ & $67.0(66.3-67.8)$ & $65.5(64.0-67.1) *$ \\
\hline & Model 2 & $68.8(67.9-69.6)$ & $66.9(66.1-67.7)$ & $65.0(63.5-66.6) \S$ \\
\hline \multicolumn{5}{|l|}{ BMI $\left(\mathrm{kg} / \mathrm{m}^{2}\right)$} \\
\hline \multirow[t]{2}{*}{ Men } & Unadjusted & $27.6(27.3-27.9)$ & $27.4(27.1-27.6)$ & $27.2(26.6-27.7)$ \\
\hline & Model 1 & $27.5(27.2-27.8)$ & $27.4(27.1-27.7)$ & $27.3(26.8-27.9)$ \\
\hline \multirow[t]{2}{*}{ Women } & Unadjusted & $26.4(26.1-26.8)$ & $25.6(25.3-25.9)$ & $24.7(24.1-25.3) \S$ \\
\hline & Model 1 & $26.4(26.0-26.7)$ & $25.6(25.3-25.9)$ & $24.8(24.2-25.4) \S$ \\
\hline \multicolumn{5}{|l|}{ Waist $(\mathrm{cm})$} \\
\hline \multirow[t]{3}{*}{ Men } & Unadjusted & $99.4(98.5-100)$ & $99.2(94.5-99.9)$ & $99.1(97.6-100.5)$ \\
\hline & Model 1 & $99.3(98.4-100.0)$ & $99.3(98.5-100.0)$ & $99.3(97.8-101.0)$ \\
\hline & Model 2 & $99.3(98.5-100.2)$ & $99.2(98.5-100.0)$ & $99.2(97.7-100.6)$ \\
\hline \multirow[t]{3}{*}{ Women } & Unadjusted & $87.9(86.7-88.7)$ & $85.7(85.0-86.5)$ & $83.6(82.1-85.1) \S$ \\
\hline & Model 1 & $87.7(86.9-88.6)$ & $85.8(85.1-86.6)$ & $83.9(82.4-85.5) \S$ \\
\hline & Model 2 & $87.7(86.9-88.6)$ & $85.0(85.8-86.6)$ & $83.9(82.4-85.5) \S$ \\
\hline
\end{tabular}

\footnotetext{
*Data are mean (confidence interval). $\uparrow: p<0.05 ; \uparrow: p<0.01 ; \S: p<0.001$. BMI, body mass index. Model 1: adjustment for age, sex, smoking status, alcohol, educational level.

Model 2: adjustment for age, sex, smoking status, alcohol, educational level and BMI (height if waist, weight if height)
} 
Table 3. Association of Blood Pressure, Lipids, Glucose and Insulin with Parental Longevity Categories*. The CoLaus study, Lausanne, Switzerland (2003-2006).

\begin{tabular}{|c|c|c|c|c|}
\hline Trait & Model & 0 parent & 1 parent & 2 parents \\
\hline SBP & Unadjusted & $136.7(135.8-137.7)$ & $135.8(134.9-136.6)$ & $134.8(133.1-136.5)$ \\
\hline \multirow[t]{2}{*}{$(\mathrm{mm} \mathrm{Hg})$} & Model 1 & $136.8(135.9-137.8)$ & $135.7(134.9-136.5)$ & $134.5(132.9-136.1)^{\dagger}$ \\
\hline & Model 2 & $136.7(135.8-137.6)$ & $135.8(135.0-136.6)$ & $134.8(133.2-136.4)$ \\
\hline DBP & Unadjusted & $81.0(80.4-81.6)$ & $80.7(80.2-81.1)$ & $80.3(79.3-81.3)$ \\
\hline \multirow[t]{2}{*}{$(\mathrm{mm} \mathrm{Hg})$} & Model 1 & $81.9(81.0-82.7)$ & $79.5(78.6-80.5)$ & $80.3(79.4-81.3)$ \\
\hline & Model 2 & $81.7(80.8-82.59$ & $79.7(78.8-80.6)$ & $80.6(79.7-81.5)$ \\
\hline PP & Unadjusted & $55.7(55.0-56.5)$ & $55.1(54.5-55.7)$ & $54.5(53.2-55.7)$ \\
\hline \multirow[t]{2}{*}{$(\mathrm{mm} \mathrm{Hg})$} & Model 1 & $55.5(54.4-56.5)$ & $55.5(54.4-56.7)$ & $54.2(53.0-55.3) \dagger$ \\
\hline & Model 2 & $55.4(54.4-56.4)$ & $55.6(54.4-56.7)$ & $54.2(53.0-55.3)^{\dagger}$ \\
\hline Cholesterol & Unadjusted & $5.79(5.7-5.9)$ & $5.79(5.7-5.8)$ & $5.79(5.7-5.9)$ \\
\hline \multirow[t]{2}{*}{$(\mathrm{mmol} / \mathrm{L})$} & Model 1 & $5.79(5.7-5.8)$ & $5.79(5.7-5.8)$ & $5.79(5.7-5.9)$ \\
\hline & Model 2 & $5.79(5.7-5.8)$ & $5.79(5.7-5.8)$ & $5.79(5.7-5.9)$ \\
\hline HDL & Unadjusted & $1.59(1.56-1.61)$ & $1.62(1.60-1.64)$ & $1.65(1.61-1.69)$ \\
\hline \multirow[t]{2}{*}{$(\mathrm{mmol} / \mathrm{L})$} & Model 1 & $1.59(1.57-1.61)$ & $1.62(1.60-1.64)$ & $1.65(1.62-1.69) \downarrow$ \\
\hline & Model 2 & $1.59(1.58-1.61)$ & $1.61(1.60-1.63)$ & $1.63(1.60-1.66)$ \\
\hline Triglycerides & Unadjusted & $1.21(1.18-1.24)$ & $1.18(1.15-1.20)$ & $1.14(1.09-1.19)^{\dagger}$ \\
\hline \multirow[t]{2}{*}{$(\mathrm{mmol} / \mathrm{L})$} & Model 1 & $1.21(1.18-1.24)$ & $1.18(1.15-1.20)$ & $1.15(1.10-1.19)$ \\
\hline & Model 2 & $1.20(1.17-1.23)$ & $1.18(1.16-1.21)$ & $1.17(1.13-1.22)$ \\
\hline Glucose & Unadjusted & $5.68(5.63-5.74)$ & $5.62(5.57-5.67)$ & $5.55(5.46-5.65)^{\dagger}$ \\
\hline \multirow[t]{2}{*}{$(\mathrm{mmol} / \mathrm{L})$} & Model 1 & $5.68(5.63-5.73)$ & $5.62(5.58-5.67)$ & $5.57(5.48-5.65)$ \\
\hline & Model 2 & $5.66(5.61-5.71)$ & $5.63(5.59-5.67)$ & $5.60(5.52-5.68)$ \\
\hline Insulin & Unadjusted & $7.91(7.66-8.16)$ & $7.85(7.64-8.06)$ & $7.79(7.38-8.22)$ \\
\hline \multirow[t]{2}{*}{$(\mathrm{U} / \mathrm{L})$} & Model 1 & $7.89(7.65-8.13)$ & $7.86(7.66-8.07)$ & $8.00(7.45-8.26)$ \\
\hline & Model 2 & $7.62(7.42-7.83)$ & $7.77(7.60-7.96)$ & $7.94(7.58-8.32)$ \\
\hline
\end{tabular}

*Data are mean (confidence interval); $\dagger: p<0.05 ; \ddagger: p<0.01 ; \xi: p<0.001$. SBP: systolic blood pressure ; DBP: diastolic blood pressure; HDL : High Density Lipoprotein cholesterol.

Model 1: adjustment for age, sex, smoking status, alcohol, educational level (antihypertensive medication for SBP, DBP, PP ; lipid lowering medication for triglycerides and cholesterol).

Model 2: adjustment for age, sex, smoking status, alcohol, educational level and BMI (height if BMI or waist, weight if height) (antihypertensive medication for SBP, DBP, PP ; lipid lowering medication for triglycerides and cholesterol) 
Table 3a. Association of Blood Pressure, Lipids, Glucose and Insulin with Parental Longevity Categories* in Never Smokers. The CoLaus study, Lausanne, Switzerland (2003-2006).

\begin{tabular}{|c|c|c|c|c|}
\hline Trait & Model & 0 parent & 1 parent & 2 parents \\
\hline SBP & Unadjusted & $137.6(136.1-139.1)$ & $136.2(134.9-137.5)$ & $134.9(132.3-137.4)$ \\
\hline \multirow[t]{2}{*}{$(\mathrm{mm} \mathrm{Hg})$} & Model 1 & $137.4(136.0-128.8)$ & $136.3(135.0-137.5)$ & $135.2(132.8-137.6)$ \\
\hline & Model 2 & $137.2(135.8-138.9)$ & $136.4(135.2-137.7)$ & $135.7(133.2-138.1)$ \\
\hline DBP & Unadjusted & $81.2(80.4-82.1)$ & $81.1(80.3-81.8)$ & $80.9(79.5-82.3)$ \\
\hline \multirow[t]{2}{*}{$(\mathrm{mm} \mathrm{Hg})$} & Model 1 & $81.3(80.5-82.1)$ & $80.7(79.8-81.6)$ & $81.9(80.1-83.8)$ \\
\hline & Model 2 & $81.1(80.3-81.9)$ & $80.8(80.0-81.7)$ & $82.3(80.4-84.1)$ \\
\hline PP & Unadjusted & $56.3(55.2-57.5)$ & $55.2(54.2-56.2)$ & $54.0(52.0-55.9)$ \\
\hline \multirow[t]{2}{*}{$(\mathrm{mm} \mathrm{Hg})$} & Model 1 & $56.1(55.1-57.2)$ & $55.9(54.7-57.0)$ & $52.6(50.2-55.0)$ \\
\hline & Model 2 & $56.1(55.0-57.1)$ & $55.9(54.8-57.0)$ & $52.7(50.2-55.1)$ \\
\hline Cholesterol & Unadjusted & $5.91(5.84-6.00)$ & $5.89(5.82-5.95)$ & $5.86(5.72-5.99)$ \\
\hline \multirow[t]{2}{*}{$(\mathrm{mmol} / \mathrm{L})$} & Model 1 & $5.92(5.84-5.99)$ & $5.89(5.82-5.95)$ & $5.86(5.72-5.99)$ \\
\hline & Model 2 & $5.91(5.84-5.99)$ & $5.88(5.81-5.95)$ & $5.86(5.73-6.00)$ \\
\hline HDL & Unadjusted & $1.62(1.59-1.66)$ & $1.68(1.65-1.71)$ & $1.74(1.68-1.81) t$ \\
\hline \multirow[t]{2}{*}{$(\mathrm{mmol} / \mathrm{L})$} & Model 1 & $1.62(1.59-1.66)$ & $1.68(1.65-1.71)$ & $1.74(1.68-1.80) t$ \\
\hline & Model 2 & $1.64(1.61-1.67)$ & $1.67(1.65-1.70)$ & $1.71(1.65-1.76)+$ \\
\hline Triglycerides & Unadjusted & $1.18(1.14-1.23)$ & $1.11(1.08-1.15)$ & $1.04(0.98-1.11) \mathrm{t}$ \\
\hline \multirow[t]{2}{*}{$(\mathrm{mmol} / \mathrm{L})$} & Model 1 & $1.18(1.13-1.23)$ & $1.11(1.09-1.15)$ & $1.05(0.99-1.12) \downarrow$ \\
\hline & Model 2 & $1.16(1.12-1.20)$ & $1.12(1.09-1.16)$ & $1.09(1.03-1.15)$ \\
\hline Glucose & Unadjusted & $5.60(5.53-5.68)$ & $5.51(5.44-5.57)$ & $5.40(5.27-5.54)^{\dagger}$ \\
\hline \multirow[t]{2}{*}{$(\mathrm{mmol} / \mathrm{L})$} & Model 1 & $5.59(5.51-5.57)$ & $5.52(5.45-5.58)$ & $5.44(5.32-5.57)$ \\
\hline & Model 2 & $5.57(5.49-5.64)$ & $5.53(5.47-5.59)$ & $5.49(5.37-5.62)$ \\
\hline Insulin & Unadjusted & $7.87(7.52-8.25)$ & $7.67(7.37-7.99)$ & $7.48(7.09-7.89)$ \\
\hline$(\mathrm{U} / \mathrm{L})$ & Model 1 & $7.86(7.51-8.22)$ & $7.68(7.39-7.99)$ & $7.51(7.13-7.91)$ \\
\hline & Model 2 & $7.55(7.24-7.86)$ & $7.67(7.40-7.94)$ & $7.81(7.28-8.38)$ \\
\hline
\end{tabular}

*Data are mean (confidence interval); $\uparrow: p<0.05 ; ;: p<0.01 ; \S: p<0.001$. SBP: systolic blood pressure ; DBP: diastolic blood pressure ; HDL : High Density Lipoprotein cholesterol.

Model 1: adjustment for age, sex, smoking status, alcohol, educational level (antihypertensive medication for SBP, DBP, PP ; lipid lowering medication for triglycerides and cholesterol).

Model 2: adjustment for age, sex, smoking status, alcohol, educational level and BMI (height if BMI or waist, weight if height) (antihypertensive medication for SBP, DBP, PP ; lipid lowering medication for triglycerides and cholesterol) 
Table 3b. Association of Blood Pressure, Lipids, Glucose and Insulin with Parental Longevity Categories* in Current and Former Smokers. The CoLaus study, Lausanne, Switzerland (2003-2006).

\begin{tabular}{|c|c|c|c|c|}
\hline Trait & Model & 0 parent & 1 parent & 2 parents \\
\hline SBP & Unadjusted & $136.1(134.9-137.4)$ & $135.4(134.2-136.5)$ & $134.7(132.5-136.9)$ \\
\hline \multirow[t]{2}{*}{$(\mathrm{mm} \mathrm{Hg})$} & Model 1 & $136.4(135.2-137.6)$ & $135.3(134.2-136.3)$ & $134.1(132.0-136.2)$ \\
\hline & Model 2 & $136.3(135.1-137.5)$ & $135.3(134.3-136.3)$ & $134.3(132.2-136.4)$ \\
\hline DBP & Unadjusted & $80.8(80.1-81.6)$ & $80.3(79.7-81.0)$ & $79.9(78.6-81.2)$ \\
\hline \multirow[t]{2}{*}{$(\mathrm{mm} \mathrm{Hg})$} & Model 1 & $82.6(81.0-84.1)$ & $78.4(76.8-80.1)$ & $78.8(77.1-80.4)$ \\
\hline & Model 2 & $82.3(80.7-83.8)$ & $78.8(77.1-80.4)$ & $79.1(77.5-80.7)$ \\
\hline PP & Unadjusted & $55.3(54.4-56.2)$ & $55.1(54.3-55.9)$ & $54.8(53.2-56.5)$ \\
\hline \multirow[t]{2}{*}{$(\mathrm{mm} \mathrm{Hg})$} & Model 1 & $55.8(53.9-57.6)$ & $54.7(52.8-56.6)$ & $54.0(52.1-55.9)$ \\
\hline & Model 2 & $55.7(54.7-56.8)$ & $54.7(53.6-55.9)$ & $54.0(51.6-56.4)$ \\
\hline Cholesterol & Unadjusted & $5.72(5.65-5.79)$ & $5.72(5.66-5.78)$ & $5.72(5.60-5.84)$ \\
\hline \multirow[t]{2}{*}{$(\mathrm{mmol} / \mathrm{L})$} & Model 1 & $5.70(5.63-5.77)$ & $5.73(5.67-5.79)$ & $5.76(5.64-5.88)$ \\
\hline & Model 2 & $5.70(5.63-5.77)$ & $5.73(5.67-5.79)$ & $5.76(5.64-5.88)$ \\
\hline HDL & Unadjusted & $1.56(1.53-1.59)$ & $1.57(1.55-1.60)$ & $1.59(1.54-1.64)$ \\
\hline \multirow[t]{2}{*}{$(\mathrm{mmol} / \mathrm{L})$} & Model 1 & $1.56(1.54-1.58)$ & $1.57(1.55-1.60)$ & $1.59(1.55-1.64)$ \\
\hline & Model 2 & $1.56(1.54-159)$ & $1.57(1.55-1.59)$ & $1.58(1.54-1.62)$ \\
\hline Triglycerides & Unadjusted & $1.23(1.20-1.28)$ & $1.23(1.19-1.26)$ & $1.22(1.15-1.29)$ \\
\hline \multirow[t]{2}{*}{$(\mathrm{mmol} / \mathrm{L})$} & Model 1 & $1.23(1.19-1.27)$ & $1.23(1.19-1.26)$ & $1.23(1.16-1.30)$ \\
\hline & Model 2 & $1.22(1.19-1.26)$ & $1.23(1.20-1.27)$ & $1.24(1.18-1-31)$ \\
\hline Glucose & Unadjusted & $5.73(5.66-5.81)$ & $5.69(5.63-5.76)$ & $5.65(5.52-5.78)$ \\
\hline \multirow[t]{2}{*}{$(\mathrm{mmol} / \mathrm{L})$} & Model 1 & $5.74(5.67-5.80)$ & $5.70(5.64-5.75)$ & $5.65(5.54-5.77)$ \\
\hline & Model 2 & $5.73(5.67-5.79)$ & $5.70(5.64-5.75)$ & $5.67(5.56-5.79)$ \\
\hline Insulin & Unadjusted & $7.93(7.60-8.27)$ & $7.97(7.68-8.27)$ & $8.01(7.45-8.61)$ \\
\hline \multirow[t]{2}{*}{$(\mathrm{U} / \mathrm{L})$} & Model 1 & $7.92(7.61-8.24)$ & $7.97(7.70-8.25)$ & $8.04(7.50-8.62)$ \\
\hline & Model 2 & $7.70(7.43-7.97)$ & $7.83(7.59-8.07)$ & $7.98(7.50-8.48)$ \\
\hline
\end{tabular}

*Data are mean (confidence interval); $\uparrow: p<0.05 ; *: p<0.01 ; \S: p<0.001$. SBP: systolic blood pressure ; DBP: diastolic blood pressure ; HDL : High Density Lipoprotein cholesterol.

Model 1: adjustment for age, sex, smoking status, alcohol, educational level (antihypertensive medication for SBP, DBP, PP ; lipid lowering medication for triglycerides and cholesterol).

Model 2: adjustment for age, sex, smoking status, alcohol, educational level and BMI (height if BMI or waist, weight if height) (antihypertensive medication for SBP, DBP, PP ; lipid lowering medication for triglycerides and cholesterol) 
Table 4. Association of Selected Cardiometabolic Variables with Parental Longevity Categories*. The CoLaus study, Lausanne, Switzerland (2003-2006).

\begin{tabular}{|c|c|c|c|c|}
\hline Trait & Model & 0 parent & 1 parent & 2 parents \\
\hline \multirow[t]{3}{*}{$\mathrm{CRP}(\mu \mathrm{mol} / \mathrm{L})$} & Unadjusted & $1.28(1.24-1.32)$ & $1.41(1.35-1.47)$ & $1.54(1.41-1.69) \S$ \\
\hline & Model 1 & $1.35(1.30-1.39)$ & $1.27(1.21-1.33)$ & $1.00(1.08-1.31)^{\dagger}$ \\
\hline & Model 2 & $1.33(1.29-1.37)$ & $1.30(1.25-1.36)$ & $1.27(1.17-1.39)$ \\
\hline \multirow[t]{3}{*}{ AST (U/L) } & Unadjusted & $28.0(27.5-28.4)$ & $27.3(26.9-27.7)$ & $26.7(26.0-27.4)$ \\
\hline & Model 1 & $28.0(27.6-28.4)$ & $27.3(26.9-27.6)$ & $27.0(26.0-27.3)^{*}$ \\
\hline & Model 2 & $27.9(27.5-28.3)$ & $27.3(27.0-27.7)$ & $26.8(26.1-27.5)^{\dagger}$ \\
\hline \multirow[t]{3}{*}{ ALT (U/L) } & Unadjusted & $23.4(22.9-24.0)$ & $23.0(22.6-23.5)$ & $22.7(21.8-23.6)$ \\
\hline & Model 1 & $23.4(22.9-23.9)$ & $23.1(22.6-23.5)$ & $23.0(21.9-23.6)$ \\
\hline & Model 2 & $23.2(22.8-23.7)$ & $23.2(22.7-23.6)$ & $23.1(22.3-23.9)$ \\
\hline \multirow[t]{3}{*}{ GGT (U/L) } & Unadjusted & $24.6(23.8-25.4)$ & $23.7(23.1-24.4)$ & $22.9(21.8-24.2)^{\dagger}$ \\
\hline & Model 1 & $24.7(24.0-25.4)$ & $23.7(23.1-24.3)$ & $23.0(21.8-24.0)$ \\
\hline & Model 2 & $24.5(23.8-25.2)$ & $23.8(23.3-24.4)$ & $23.2(22.1-24.4)$ \\
\hline Adiponectin & Unadjusted & $7.69(7.54-7.84)$ & $8.32(8.09-8.55)$ & $8.00(8.52-9.50) \S$ \\
\hline \multirow[t]{2}{*}{$(\mathrm{mg} / \mathrm{mL})$} & Model 1 & $7.87(7.73-8.02)$ & $7.90(7.69-8.12)$ & $7.93(7.51-8.38)$ \\
\hline & Model 2 & $7.91(7.76-8.01)$ & $7.85(7.64-8.05)$ & $7.78(7.37-8.22)$ \\
\hline Leptin Men & Unadjusted & $7.34(6.90-7.81)$ & $7.47(7.09-7.87)$ & $7.60(6.85-8.43)$ \\
\hline \multirow[t]{2}{*}{$(\mathrm{ng} / \mathrm{mL})$} & Model 1 & $7.31(6.88-7.78)$ & $7.48(7.04-7.96)$ & $7.66(6.90-8.50)$ \\
\hline & Model 2 & $7.29(6.93-7.66)$ & $7.50(7.19-7.83)$ & $7.73(7.10-8.42)$ \\
\hline Leptin Women & Unadjusted & $15.4(14.6-16.3)$ & $14.2(13.5-14.8)$ & $13.0(11.9-14.3)^{t}$ \\
\hline \multirow[t]{2}{*}{$(\mathrm{ng} / \mathrm{mL})$} & Model 1 & $15.3(14.5-16.1)$ & $14.3(13.6-14.9)$ & $13.3(12.1-14.6)^{\dagger}$ \\
\hline & Model 2 & $14.8(14.1-15.4)$ & $14.6(14.1-15.2)$ & $14.5(13.5-15.6)$ \\
\hline Homocysteine & Unadjusted & $10.5(10.4-10.7)$ & $10.5(10.4-10.7)$ & $10.6(10.3-10.8)$ \\
\hline \multirow[t]{2}{*}{$(\mu \mathrm{mol} / \mathrm{L})$} & Model 1 & $10.6(10.4-10.7)$ & $10.5(10.4-10.6$ & $10.0(10.2-10.7)$ \\
\hline & Model 2 & $10.5(10.4-10.7)$ & $10.5(10.4-10.6)$ & $10.5(10.2-10.8)$ \\
\hline Uric acid & Unadjusted & $332(328-336)$ & $327(324-331)$ & $323(315-330)$ \\
\hline \multirow[t]{2}{*}{$(\mu \mathrm{mol} / \mathrm{L})$} & Model 1 & $333(329-337)$ & $327(324-330)$ & $321(314-328) *$ \\
\hline & Model 2 & $331(328-335)$ & $328(325-331)$ & $324(318-331)$ \\
\hline
\end{tabular}

*Data are mean (confidence interval). $\uparrow: p<0.05 ; *: p<0.01 ; \xi: p<0.001$. CRP, C-Reactive Protein ; AST, Aspartate Aminotransferase; ALT, Alanine Aminotransferase ; GGT, Gamma Glutamyl Transferase; ALKP, Alkaline Phosphatase.

Model 1: adjustment for age, sex, smoking status, alcohol, educational level.

Model 2: adjustment for age, sex, smoking status, alcohol, educational level and BMI (height if BMI or waist, weight if height). 
Table 4a. Association of Selected Cardiometabolic Variables with Parental Longevity Categories* in Never Smokers. The CoLaus study, Lausanne, Switzerland (2003-2006).

\begin{tabular}{|c|c|c|c|c|}
\hline Trait & Model & 0 parent & 1 parent & 2 parents \\
\hline \multirow[t]{3}{*}{$\mathrm{CRP}(\mu \mathrm{mol} / \mathrm{L})$} & Unadjusted & $1.75(1.61-1.91)$ & $1.56(1.45-1.68)$ & $1.40(1.21-1.62)^{\dagger}$ \\
\hline & Model 1 & $1.74(1.60-1.90)$ & $1.57(1.46-1.69)$ & $1.42(1.23-1.64)^{\dagger}$ \\
\hline & Model 2 & $1.66(1.54-1.79)$ & $1.62(1.52-1.73)$ & $1.58(1.38-1.79)$ \\
\hline \multirow[t]{3}{*}{ AST (U/L) } & Unadjusted & $27.5(27.0-28.1)$ & $27.1(26.6-27.6)$ & $26.7(25.8-27.6)^{\dagger}$ \\
\hline & Model 1 & $27.8(27.2-28.4)$ & $27.1(26.6-27.6)$ & $26.6(25.7-27.6)$ \\
\hline & Model 2 & $27.5(26.9-28.1)$ & $27.1(26.7-27.6)$ & $26.8(25.9-27.8)$ \\
\hline \multirow[t]{3}{*}{ ALT $(\mathrm{U} / \mathrm{L})$} & Unadjusted & $23.3(22.6-24.1)$ & $22.5(21.8-23.1)$ & $21.7(20.5-22.9) \dagger$ \\
\hline & Model 1 & $23.3(22.6-24.1)$ & $22.5(21.9-23.1)$ & $21.7(20.5-22.9) \dagger$ \\
\hline & Model 2 & $23.1(22.4-23.9)$ & $22.6(22.0-23.2)$ & $22.1(21.0-23.3)$ \\
\hline \multirow[t]{3}{*}{ GGT (U/L) } & Unadjusted & $23.2(22.1-24.3)$ & $22.2(21.3-23.1)$ & $21.2(19.7-23,0)$ \\
\hline & Model 1 & $23.2(22.2-24.2)$ & $22.2(21.4-23.1)$ & $21.3(19.8-22.9)$ \\
\hline & Model 2 & $22.9(21.9-24.0)$ & $22.3(21.5-23.2)$ & $21.8(20.3-23.5)$ \\
\hline \multirow{3}{*}{$\begin{array}{l}\text { Adiponectin } \\
(\mathrm{mg} / \mathrm{mL})\end{array}$} & Unadjusted & $9.21(8.71-9.73)$ & $9.69(9.23-10.17)$ & $10.20(9.26-11.21)$ \\
\hline & Model 1 & $9.21(8.74-9.71)$ & $9.68(9.25-10.13)$ & $10.16(9.29-11.13)$ \\
\hline & Model 2 & $9.34(8.97-9.72)$ & $9.61(9.20-10.03)$ & $9.89(9.05-10.80)$ \\
\hline \multirow{3}{*}{$\begin{array}{l}\text { Leptin Men } \\
(\mathrm{ng} / \mathrm{mL})\end{array}$} & Unadjusted & $6.74(6.04-7.52)$ & $7.07(6.43-7.77)$ & $7.41(6.15-9.92)$ \\
\hline & Model 1 & $6.73(6.02-7.52)$ & $7.07(6.44-7.77)$ & $7.39(6.12-8.92)$ \\
\hline & Model 2 & $6.69(6.09-7.35)$ & $7.10(6.46-7.80)$ & $7.54(6.44-8.82)$ \\
\hline \multirow{3}{*}{$\begin{array}{l}\text { Leptin Women } \\
(\mathrm{ng} / \mathrm{mL})\end{array}$} & Unadjusted & $16.61(15.46-17.85)$ & $14.73(13.85-15.67)$ & $13.05(11.55-14.75) t$ \\
\hline & Model 1 & $16.54(15.40-17.78)$ & $14.81(13.92-15.75)$ & $13.25(11.72-14.99) \downarrow$ \\
\hline & Model 2 & $15.83(14.94-16.77)$ & $15.24(14.51-16.00)$ & $14.66(13.27-16.19)$ \\
\hline \multirow{3}{*}{$\begin{array}{l}\text { Homocysteine } \\
(\mu \mathrm{mol} / \mathrm{L})\end{array}$} & Unadjusted & $10.3(10.1-10.5)$ & $10.1(10.0-10.3)$ & $10.0(9.7-10.4)$ \\
\hline & Model 1 & $10.2(10.0-10.5)$ & $10.1(10.0-10.3)$ & $10.0(9.7-10.4)$ \\
\hline & Model 2 & $10.2(10.0-10.4)$ & $10.1(10.0-10.3)$ & $10.1(9.7-10.5)$ \\
\hline \multirow{3}{*}{$\begin{array}{l}\text { Uric acid } \\
(\mu \mathrm{mol} / \mathrm{L})\end{array}$} & Unadjusted & $320(314-326)$ & $314(308-319)$ & $307(296-318)$ \\
\hline & Model 1 & $320(314-326)$ & $314(309-319)$ & $308(298-318)$ \\
\hline & Model 2 & $318(312-323)$ & $315(311-320)$ & $313(304-323)$ \\
\hline
\end{tabular}

*Data are mean (confidence interval). $\uparrow: p<0.05 ; \$: p<0.01 ; \S: p<0.001$. CRP, C-Reactive Protein ; AST, Aspartate Aminotransferase; ALT, Alanine Aminotransferase ; GGT, Gamma Glutamyl Transferase; ALKP, Alkaline Phosphatase.

Model 1: adjustment for age, sex, smoking status, alcohol, educational level.

Model 2: adjustment for age, sex, smoking status, alcohol, educational level and BMI (height if BMI or waist, weight if height). 
Table 4b. Association of Selected Cardiometabolic Variables with Parental Longevity Categories* in Current and Former Smokers. The CoLaus study, Lausanne, Switzerland (20032006).

\begin{tabular}{|c|c|c|c|c|}
\hline Trait & Model & 0 parent & 1 parent & 2 parents \\
\hline \multirow[t]{3}{*}{$\mathrm{CRP}(\mu \mathrm{mol} / \mathrm{L})$} & Unadjusted & $1.75(1.63-1.88)$ & $1.63(1.53-1.73)$ & $1.52(1.34-1.71)$ \\
\hline & Model 1 & $1.74(1.62-1.87)$ & $1.64(1.54-1.74)$ & $1.54(1.36-1.74)$ \\
\hline & Model 2 & $1.72(1.61-1.84)$ & $1.65(1.55-1.75)$ & $1.58(1.40-1.77)$ \\
\hline \multirow[t]{3}{*}{$\operatorname{AST}(\mathrm{U} / \mathrm{L})$} & Unadjusted & $27.9(27.3-28.5)$ & $27.4(26.9-28.0)$ & $26.6(25.7-27.7) \dagger$ \\
\hline & Model 1 & $28.3(27.7-28.9)$ & $27.4(26.9-27.9)$ & $26.6(25.6-27.5) \dagger$ \\
\hline & Model 2 & $28.2(27.6-28.9)$ & $27.4(26.9-27.9)$ & $26.7(25.7-27.6)+$ \\
\hline \multirow[t]{3}{*}{ ALT (U/L) } & Unadjusted & $23.5(22.8-24.2)$ & $23.4(22.8-24.1)$ & $23.4(22.2-24.7)$ \\
\hline & Model 1 & $23.4(22.8-24.1)$ & $23.5(22.9-24.1)$ & $23.5(22.3-24.7)$ \\
\hline & Model 2 & $23.3(22.7-24.0)$ & $23.5(23.0-24.1)$ & $23.8(22.6-25.0)$ \\
\hline \multirow[t]{3}{*}{ GGT (U/L) } & Unadjusted & $25.6(24.6-26.8)$ & $24.9(24.0-25.9)$ & $24.2(22.6-26.1)$ \\
\hline & Model 1 & $25.7(24.8-26.8)$ & $24.9(24.1-25.7)$ & $24.0(22.6-25.7)$ \\
\hline & Model 2 & $25.6(24.7-26.6)$ & $24.9(24.2-25.8)$ & $24.3(22.8-25.9)$ \\
\hline Adiponectin & Unadjusted & $8.35(7.98-8.74)$ & $8.10(7.79-8.43)$ & $7.94(7.34-8.60)$ \\
\hline \multirow[t]{2}{*}{$(\mathrm{mg} / \mathrm{mL})$} & Model 1 & $8.43(8.08-8.80)$ & $8.17(7.87-8.48)$ & $7.91(7.34-8.52)$ \\
\hline & Model 2 & $8.50(8.16-8.86)$ & $8.10(7.81-8.40)$ & $7.84(7.29-8.43)$ \\
\hline Leptin Men & Unadjusted & $7.58(7.05-8.15)$ & $7.62(7.16-8.12)$ & $7.66(6.76-8.68)$ \\
\hline \multirow[t]{2}{*}{$(\mathrm{ng} / \mathrm{mL})$} & Model 1 & $7.56(7.02-8.13)$ & $7.64(7.18-8.14)$ & $7.73(6.82-8.77)$ \\
\hline & Model 2 & $7.53(7.10-7.98)$ & $7.66(7.29-8.05)$ & $7.80(7.06-8.63)$ \\
\hline \multirow{3}{*}{$\begin{array}{l}\text { Leptin Women } \\
(\mathrm{ng} / \mathrm{mL})\end{array}$} & Unadjusted & $14.20(13.14-15.35)$ & $13.58(12.67-14.55)$ & $12.98(11.31-14.91)$ \\
\hline & Model 1 & $14.07(13.02-15.20)$ & $13.67(12.77-14.65)$ & $13.29(11.57-15.27)$ \\
\hline & Model 2 & $13.70(12.90-14.55)$ & $13.94(13.22-14.70)$ & $14.18(12.74-15.79)$ \\
\hline \multirow{3}{*}{$\begin{array}{l}\text { Homocysteine } \\
(\mu \mathrm{mol} / \mathrm{L})\end{array}$} & Unadjusted & $10.7(10.5-10.9)$ & $10.8(10.6-11.0)$ & $10.9(10.6-11.4)$ \\
\hline & Model 1 & $10.8(10.6-11.0)$ & $10.8(10.6-11.0)$ & $10.8(10.4-11.2)$ \\
\hline & Model 2 & $10.8(10.6-11.0)$ & $10.8(10.6-11.0)$ & $10.8(10.4-11.2)$ \\
\hline \multirow{3}{*}{$\begin{array}{l}\text { Uric acid } \\
(\mu \mathrm{mol} / \mathrm{L})\end{array}$} & Unadjusted & $340(334-346)$ & $337(332-342)$ & $334(324-344)$ \\
\hline & Model 1 & $341(336-346)$ & $336(331-340)$ & $330(321-339)$ \\
\hline & Model 2 & $340(336-345)$ & $336(332-341)$ & $332(324-341)$ \\
\hline
\end{tabular}

*Data are mean (confidence interval). $\uparrow: p<0.05 ; \hbar: p<0.01 ; \S: p<0.001$. CRP, C-Reactive Protein ; AST, Aspartate Aminotransferase; ALT, Alanine Aminotransferase ; GGT, Gamma Glutamyl Transferase; ALKP, Alkaline Phosphatase.

Model 1: adjustment for age, sex, smoking status, alcohol, educational level.

Model 2: adjustment for age, sex, smoking status, alcohol, educational level and BMI (height if BMI or waist, weight if height). 
Table 5. Framingham Risk Score by Parental Longevity Categories, overall and by smoking status.* The CoLaus study, Lausanne, Switzerland (2003-2006).

\begin{tabular}{|c|c|c|c|}
\hline Framingham Risk Score & 0 parent & 1 parent & 2 parents \\
\hline Men & $\begin{array}{l}11.74(11.27-12.20) \\
(n=580)\end{array}$ & $\begin{array}{l}11.75(11.26-12.24) \\
(\mathrm{n}=453)\end{array}$ & $\begin{array}{l}11.00(10.58-11.44) \\
(n=130)\end{array}$ \\
\hline Women & $\begin{array}{l}3.11(2.91-3.30) \\
(n=7.18)\end{array}$ & $\begin{array}{l}3.12(2.95-3.29) \\
(n=538)\end{array}$ & $\begin{array}{l}2.51(2.38-2.64) \dagger \\
(n=142)\end{array}$ \\
\hline Non-smoking men & $\begin{array}{l}9.33(8.44-10.23) \\
(n=163)\end{array}$ & $\begin{array}{l}9.31(8.22-10.40) \\
(n=117)\end{array}$ & $\begin{array}{l}8.57(6.90-10.24) \\
(n=38)\end{array}$ \\
\hline Non-smoking women & $\begin{array}{l}2.71(2.46-2.95) \\
(n=370)\end{array}$ & $\begin{array}{l}2.60(2.37-2.83) \\
(n=280)\end{array}$ & $\begin{array}{l}1.99(1.62-2.36) \dagger \\
(n=79)\end{array}$ \\
\hline $\begin{array}{l}\text { Smoking men } \\
\text { (former and current) }\end{array}$ & $\begin{array}{l}12.67(11.85-13.50) \\
(n=417)\end{array}$ & $\begin{array}{l}12.60(11.58-13.61) \\
(n=336)\end{array}$ & $\begin{array}{l}12.02(10.41-13.63) \\
(n=92)\end{array}$ \\
\hline $\begin{array}{l}\text { Smoking women } \\
\text { (former and current) }\end{array}$ & $\begin{array}{l}3.53(3.04-4.03) \\
(\mathrm{n}=348)\end{array}$ & $\begin{array}{l}3.68(3.16-4.20) \\
(\mathrm{n}=258)\end{array}$ & $\begin{array}{l}3.16(2.43-3.89) \\
(n=63)\end{array}$ \\
\hline
\end{tabular}

*Data are mean (confidence interval)

$\uparrow: p<0.05$ 
Figure legends.

Figure 1. Relationship between Anthropometric Variables and Categories of Parental Longevity, by Sex. The CoLaus study, Lausanne, Switzerland (2003-2006). Upper panels: BMI. Middle panels: Weight. Lower panels: Waist circumference.

Figure 2. Age-adjusted Prevalence of the Metabolic Syndrome by Categories of Parental Longevity, Smoking Status and Sex. The CoLaus study, Lausanne, Switzerland (20032006).

Numbers on top of bars represent sample sizes. 0,1 and 2 labels on the $\mathrm{x}$ axis represent the number of long-lived parents. Age-adjustment was done using direct standardization in Stata. 
Figure 1.

WOMEN
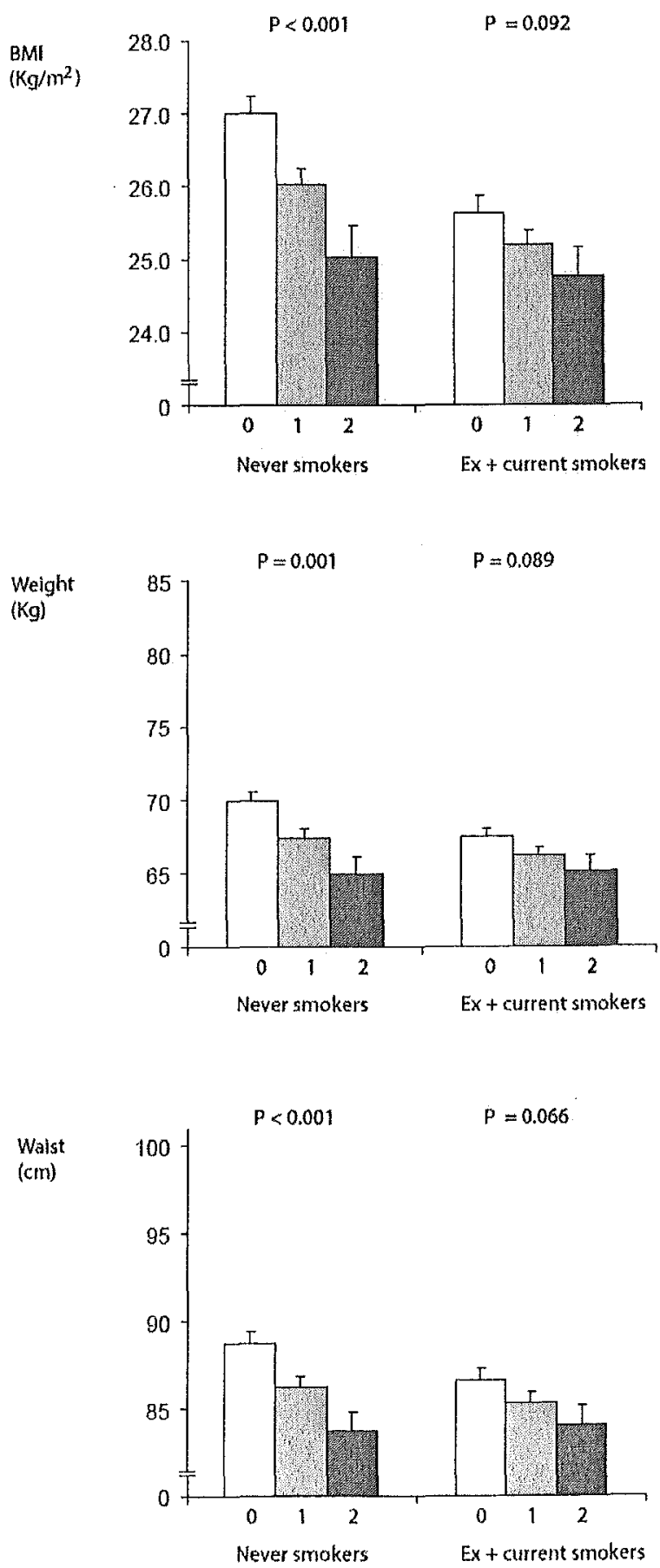

MEN
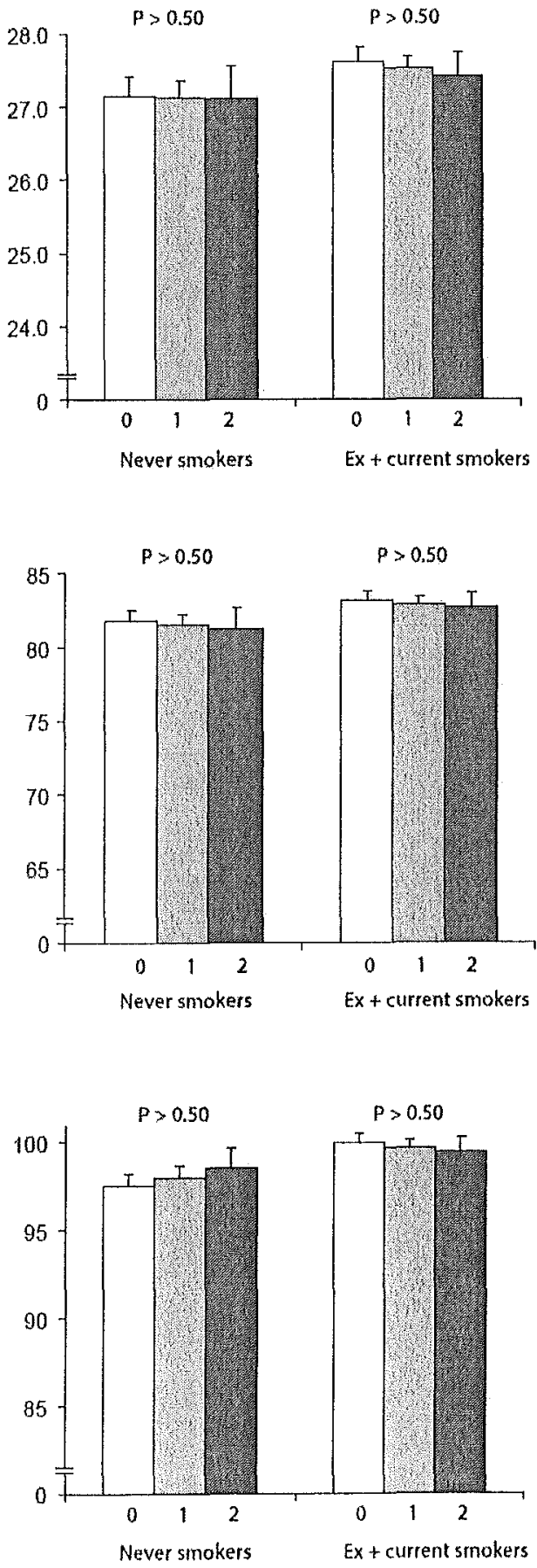
Figure 2.

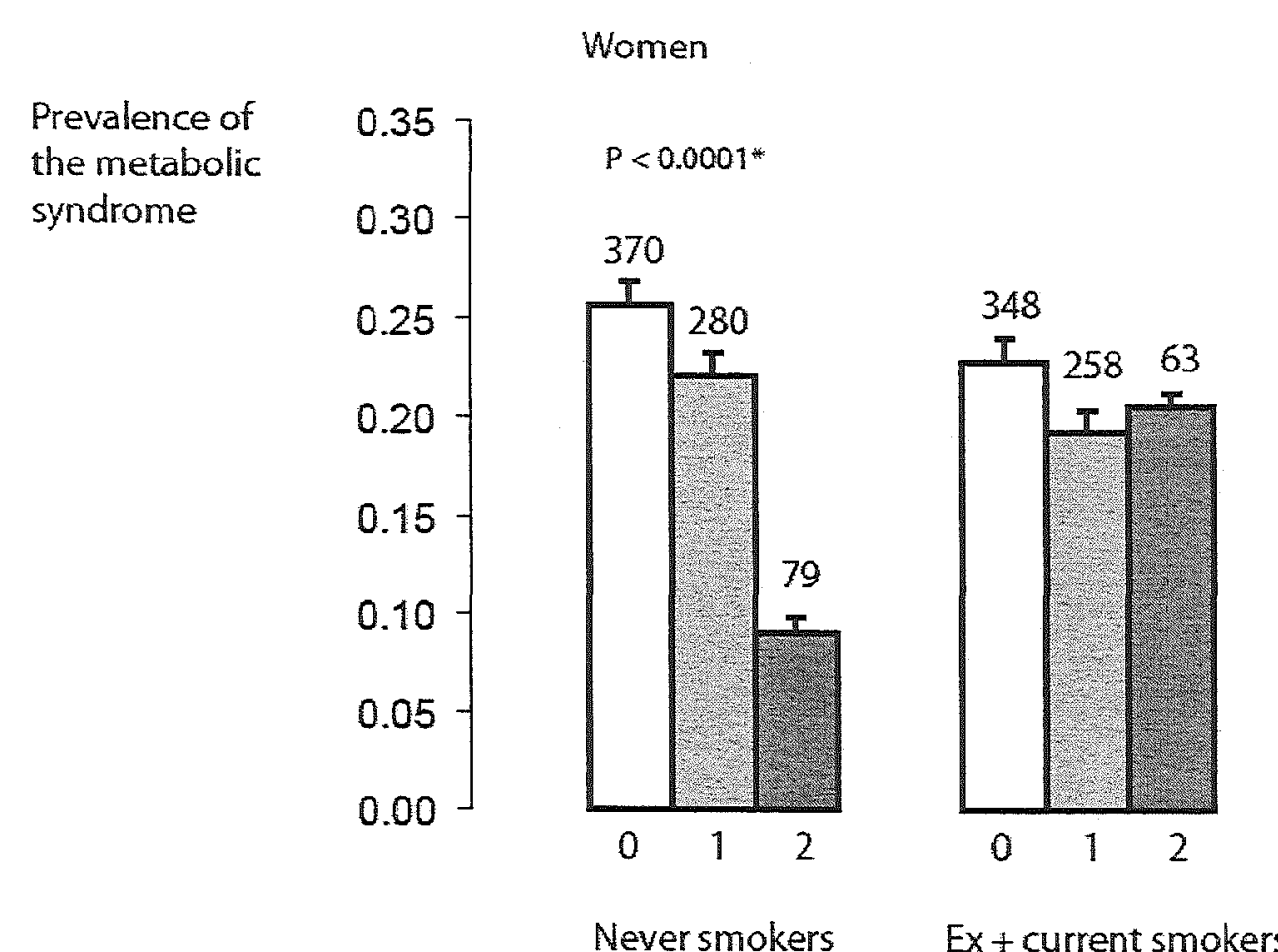

Men

* Pvalue for linear trend

Numbers above the bars are the number of participants

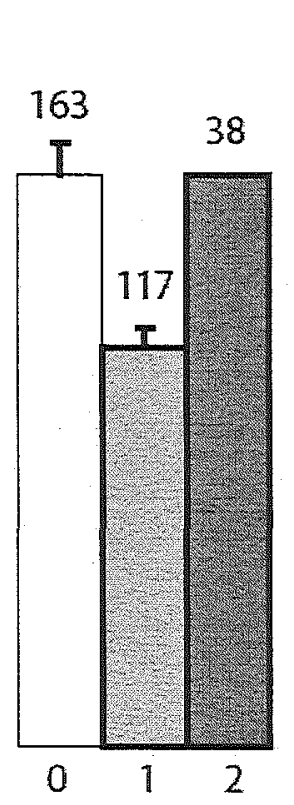

Never smokers

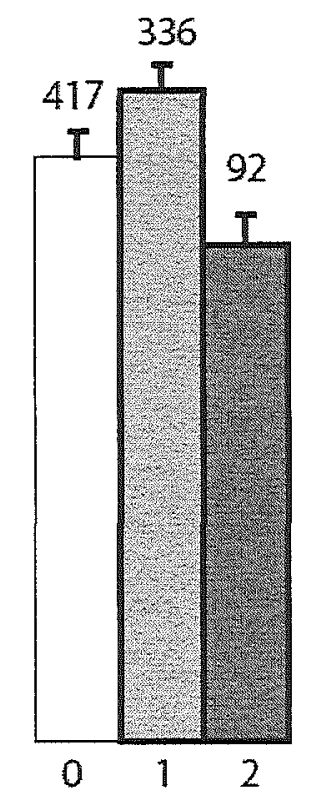

Ex+current smokers 


\section{Reference List}

Adult Treatment Panel III, 2002. Third Report of the National Cholesterol Education Program (NCEP) Expert Panel on Detection, Evaluation, and Treatment of High Blood Cholesterol in Adults (Adult Treatment Panel III) final report. Circulation 106, 3143-3421.

Atzmon, G., Schechter, C., Greiner, W., Davidson, D., Rennert, G., Barzilai, N., 2004. Clinical phenotype of families with longevity. J. Am. Geriatr. Soc. 52, 274-277.

Barzilai, N., Gabriely, I., Gabriely, M., Iankowitz, N., Sorkin, J.D., 2001. Offspring of centenarians have a favorable lipid profile. J. Am. Geriatr. Soc. 49, 76-79.

Bensen, J.T., Liese, A.D., Rushing, J.T., Province, M., Folsom, A.R., Rich, S.S., Higgins, M., 1999. Accuracy of proband reported family history: the NHLBI Family Heart Study (FHS). Genet Epidemiol 17, 141-150.

Bernhard, D., Moser, C., Backovic, A., Wick, G., 2007. Cigarette smoke--an aging accelerator? Exp. Gerontol. 42, 160-165.

El Assaad, M.A., Topouchian, J.A., Darne, B.M., Asmar, R.G., 2002. Validation of the Omron HEM-907 device for blood pressure measurement. Blood Press Monit. 7, 237-241.

Firmann, M., Mayor, V., Marques-Vidal, P.M., Bochud, M., Pecoud, A., Paccaud, F., Preisig, M., Song, K.S., Yuan, X., Danoff, T.M., Stirnadel, H., Waterworth, D.M., Mooser, V., Waeber, G., Vollenweider, P., 2008. The CoLaus study: a population-based study to investigate the epidemiology and genetic determinants of cardiovascular risk factors and metabolic syndrome. BMC Cardiovasc Disord 8, 6.

Galea, S., Tracy, M., 2007. Participation rates in epidemiologic studies. Ann Epidemiol 17, 643-653. 
Grundy, S.M., 2007. Metabolic syndrome: a multiplex cardiovascular risk factor. J Clin Endocrinol Metab 92, 399-404.

Hammond, E.C., Garfinkel, L., Seidman, H., 1971. Longevity of parents and grandparents in relation to coronary heart disease and associated variables. Circulation 43, 31-44.

Ikeda, A., Iso, H., Toyoshima, H., Kondo, T., Mizoue, T., Koizumi, A., Inaba, Y., Tamakoshi, A., 2006. Parental longevity and mortality amongst Japanese men and women: the JACC Study. J. Intern. Med. 259, 285-295.

Karter, A.J., Rowell, S.E., Ackerson, L.M., Mitchell, B.D., Ferrara, A., Selby, J.V., Newman, B., 1999. Excess maternal transmission of type 2 diabetes. The Northern California Kaiser Permanente Diabetes Registry. Diabetes Care 22, 938-943.

Marques-Vidal, P., Pecoud, A., Hayoz, D., Paccaud, F., Mooser, V., Waeber, G., Vollenweider, P., 2007. Prevalence and characteristics of vitamin or dietary supplement users in Lausanne, Switzerland: the CoLaus study. Eur J Clin Nutr [Epub ahead of print].

Marques-Vidal, P., Pecoud, A., Hayoz, D., Paccaud, F., Mooser, V., Waeber, G., Vollenweider, P., 2008. Prevalence and characteristics of homeopathy users in a representative sample of the Lausanne population: CoLaus study. Pharmacoepidemiol. Drug Saf $17,209-211$

Martin, G.M., 2000. Some new directions for research on the biology of aging. Ann. N. Y. Acad. Sci. 908, 1-13.

Martin, G.M., Bergman, A., Barzilai, N., 2007. Genetic determinants of human health span and life span: progress and new opportunities. PLoS. Genet. 3, e125. 
Menotti, A., Lanti, M., Maiani, G., Kromhout, D., 2006. Determinants of longevity and allcause mortality among middle-aged men. Role of 48 personal characteristics in a 40 -year follow-up of Italian Rural Areas in the Seven Countries Study. Aging Clin. Exp. Res. 18, 394-406.

Muller-Nordhorn, J., Binting, S., Roll, S., Willich, S.N., 2008. An update on regional variation in cardiovascular mortality within Europe. Eur. Heart J.

Murabito, J.M., Nam, B.H., D'Agostino, R.B., Sr., Lloyd-Jones, D.M., O'Donnell, C.J., Wilson, P.W., 2004. Accuracy of offspring reports of parental cardiovascular disease history: the Framingham Offspring Study. Ann Intern Med 140, 434-440.

Perls, T.T., Wilmoth, J., Levenson, R., Drinkwater, M., Cohen, M., Bogan, H., Joyce, E., Brewster, S., Kunkel, L., Puca, A., 2002. Life-long sustained mortality advantage of siblings of centenarians. Proc. Natl. Acad. Sci. U. S. A 99, 8442-8447.

Rainio, S.U., Rimpela, A.H., Luukkaala, T.H., Rimpela, M.K., 2008. Evolution of the association between parental and child smoking in Finland between 1977 and 2005. Prev Med 46, 565-571.

Reed, T., Carmelli, D., Robinson, T.S., Rinehart, S.A., Williams, C.J., 2003. More favorable midlife cardiovascular risk factor levels in male twins and mortality after 25 years of followup is related to longevity of their parents. J. Gerontol. A Biol. Sci. Med. Sci. 58, 367-371.

Rodondi, N., Cornuz, J., Marques-Vidal, P., Butler, J., Hayoz, D., Pecoud, A., Paccaud, F., Waeber, G., Vollenweider, P., 2008. Aspirin use for the primary prevention of coronary heart disease: A population-based study in Switzerland. Prev Med 46, 137-144. 
Rosengren, A., Thelle, D., Wilhelmsen, L., 2002. Parental age and coronary disease in the general male population. J. Intern. Med. 251, 258-267.

Sandhu, M.S., Waterworth, D.M., Debenham, S.L., Wheeler, E., Papadakis, K., Zhao, J.H., Song, K., Yuan, X., Johnson, T., Ashford, S., Inouye, M., Luben, R., Sims, M., Hadley, D., McArdle, W., Barter, P., Kesaniemi, Y.A., Mahley, R.W., McPherson, R., Grundy, S.M., Bingham, S.A., Khaw, K.T., Loos, R.J., Waeber, G., Barroso, I., Strachan, D.P., Deloukas, P., Vollenweider, P., Wareham, N.J., Mooser, V., 2008. LDL-cholesterol concentrations: a genome-wide association study. Lancet 371, 483-491.

Suzman, R., Riley, M.W., 1985. Introducing the "oldest old". Milbank Mem. Fund. Q. Health Soc. $63,177-186$.

Taylor, A.W., Dal, G.E., Gill, T., Chittleborough, C.R., Wilson, D.H., Adams, R.J., Grant, J.F., Phillips, P., Ruffin, R.E., 2006. Do people with risky behaviours participate in biomedical cohort studies? BMC Public Health 6, 11 .

Terry, D.F., Evans, J.C., Pencina, M.J., Murabito, J.M., Vasan, R.S., Wolf, P.A., KellyHayes, M., Levy, D., D'Agostino, R.B., Sr., Benjamin, E.J., 2007. Characteristics of Framingham offspring participants with long-lived parents. Arch. Intern. Med. 167, 438-444.

Terry, D.F., Wilcox, M., McCormick, M.A., Lawler, E., Perls, T.T., 2003. Cardiovascular advantages among the offspring of centenarians. J. Gerontol. A Biol. Sci. Med. Sci. 58, M425-M431.

Terry, D.F., Wilcox, M.A., McCormick, M.A., Pennington, J.Y., Schoenhofen, E.A., Andersen, S.L., Perls, T.T., 2004. Lower all-cause, cardiovascular, and cancer mortality in centenarians' offspring. J. Am. Geriatr. Soc. 52, 2074-2076. 
Tunstall-Pedoe, H., Kuulasmaa, K., Mahonen, M., Tolonen, H., Ruokokoski, E., Amouyel, P., 1999. Contribution of trends in survival and coronary-event rates to changes in coronary heart disease mortality: 10-year results from 37 WHO MONICA project populations. Monitoring trends and determinants in cardiovascular disease. Lancet 353, 1547-1557.

Wilson, P.W., D'Agostino, R.B., Levy, D., Belanger, A.M., Silbershatz, H., Kannel, W.B., 1998. Prediction of coronary heart disease using risk factor categories. Circulation 97, 1837 1847.

Wolf, H.K., Kuulasmaa, K., Tolonen, H., Sans, S., Molarius, A., Eastwood, B.J., 2005. Effect of sampling frames on response rates in the WHO MONICA risk factor surveys. Eur $\mathrm{J}$ Epidemiol 20, 293-299.

Yarnell, J., Yu, S., Patterson, C., Cambien, F., Arveiler, D., Amouyel, P., Ferrieres, J., Luc, G., Evans, A., Ducimetiere, P., 2003. Family history, longevity, and risk of coronary heart disease: the PRIME Study. Int. J. Epidemiol. 32, 71-77.

Yusuf, S., Hawken, S., Ounpuu, S., Dans, T., Avezum, A., Lanas, F., McQueen, M., Budaj, A., Pais, P., Varigos, J., Lisheng, L., 2004. Effect of potentially modifiable risk factors associated with myocardial infarction in 52 countries (the INTERHEART study): casecontrol study. Lancet 364, 937-952.

Zureik, M., Galan, P., Bertrais, S., Courbon, D., Czernichow, S., Blacher, J., Ducimetiere, P., Safar, M.E., Hercberg, S., 2005. Parental longevity and 7-year changes in blood pressures in adult offspring. Hypertension 46, 287-294. 